\title{
Educação, concentração fundiária e desigualdade de rendimentos no meio rural brasileiro
}

\author{
Marlon Gomes Ney ${ }^{1}$ \\ Rodolfo Hoffmann²
}

Resumo: $\mathrm{O}$ artigo estuda os efeitos dos fatores determinantes da renda rural, particularmente do capital humano e do capital físico. Além de equações de rendimentos ajustadas para o setor primário, foram analisadas regressões de renda para a população ocupada na indústria e no setor de serviços. Os resultados obtidos revelam que, embora o capital físico seja o principal determinante da concentração da renda agrícola, é a educação o fator que explica a maior parcela da desigualdade de rendimentos nas atividades não-agrícolas e no meio rural como um todo.

Palavras-chaves: renda, capital humano, capital físico, meio rural.

Classificação JEL: Q15, D31.

\begin{abstract}
The paper analyses the effects of rural income determinants, in particular of human capital and physical capital. Besides the earnings equation estimated for persons occupied in agriculture, the paper also analyzes earnings regressions for persons occupied in the industry and service sectors. The results show that physical capital is the main determinant of earnings in Brazilian agriculture, but schooling is the most important determinant of earnings for persons occupied in rural non-farm activities and for all persons living in rural areas.
\end{abstract}

Key-words: income, human capital, physical capital, rural, Brazil.

JEL Classification: Q15, D31.

${ }^{1}$ Professor do Centro de Ciências do Homem da UENF. E-mail: marlonney@uenf.br

2 Professor do Instituto de Economia da Unicamp. E-mail: rhoffman@esalq.usp.br 


\section{Introdução}

A educação influencia de várias formas a qualidade de vida das pessoas. Ela não só afeta positivamente o nível de produtividade e renda do trabalho, como também uma população mais educada torna-se capaz de participar de forma mais ativa na vida social e política do País. Do ponto de vista demográfico, uma maior escolaridade está associada a menores níveis de fecundidade e de mortalidade, visto que permite uma melhor compreensão sobre as práticas de planejamento familiar e saúde preventiva.

As estatísticas sobre educação, em qualquer país ou região, assumem posição de destaque nos estudos que analisam as características socioeconômicas da população, buscando identificar suas principais carências e prioridades para a adoção de políticas públicas a favor do desenvolvimento. No meio rural de países subdesenvolvidos, em particular, Lanjouw (1999) e Reardon (2001) destacam que o baixo nível de escolaridade da população restringe o crescimento das atividades não-agrícolas, principalmente das mais produtivas e dinâmicas. Outra preocupação, ainda mais grave, é o fato de o nível de investimento em capital humano ser tão menor quanto mais pobre é a família.

Estudos realizados em diversos países em desenvolvimento mostram que algumas condições responsáveis pela desigualdade de renda na agricultura, como a distribuição da posse da terra, o perfil educacional da população e as desigualdades inter-regionais também tendem a afetar, com maior ou menor intensidade, a distribuição da renda RNA (rural não-agrícola). Em relação especificamente à escolaridade, o desempenho educacional é considerado um condicionante importantíssimo para a obtenção de empregos com maiores salários no setor industrial e no de serviços e para a realização e o sucesso de atividades não-agrícolas em empreendimentos outrora voltados apenas à produção de bens primários. Embora a distribuição da posse da terra seja a variável preponderante na explicação da desigualdade de renda na agricultura brasileira, segundo os trabalhos sobre o tema no País, pesquisas recentes 
desenvolvidas em outros países sugerem que nas atividades rurais não-agrícolas sua influência seria inferior à da educação.

Nesse sentido, é importante buscar um maior entendimento sobre os efeitos dos principais mecanismos responsáveis pelas disparidades de renda do trabalho rural no Brasil, em que, além dos agricultores, também fossem consideradas as pessoas ocupadas na indústria e nos serviços. Nas áreas rurais do País, a participação das atividades não-agrícolas na geração de emprego, posições de trabalho e renda podem contribuir para a redução da influência da posse da terra e o aumento do efeito da educação na conformação da renda. A próxima seção mostrará algumas evidências em defesa desse argumento.

Na seção 3, será definida a base de dados utilizada na pesquisa e serão analisadas suas principais limitações. Ela é composta pelas informações coletadas na pesquisa amostral do Censo Demográfico de 2000. Na coleta das informações do censo, o IBGE utilizou dois modelos de questionário. O primeiro foi o questionário básico, contendo perguntas referentes às características investigadas para toda população. O segundo questionário foi aplicado apenas nos domicílios selecionados para a realização de uma pesquisa amostral, na qual, além das variáveis investigadas no questionário básico, procurou-se obter outras informações sobre características dos domicílios e de seus moradores referentes a temas como escolaridade, trabalho e rendimento, fundamentais para este estudo.

A fim de analisar o efeito da educação na desigualdade de renda no meio rural brasileiro, na seção 4 serão analisadas as principais características da distribuição da renda em todo o Brasil, no meio rural e urbano, procurando associar o nível de desigualdade de renda em cada situação de domicílio com o perfil educacional da população. No item 5 , serão ajustadas, ainda, equações de rendimentos para pessoas ocupadas em atividades agrícolas e não-agrícolas, utilizando as seguintes variáveis: sexo, cor, idade, escolaridade, posição na ocupação e região. Trata-se de variáveis de uso comum na literatura, sendo consideradas como proxies razoáveis para captar os efeitos da discriminação por gênero e raça, da educação, do capital físico e dos contrastes de desenvolvimento entre regiões. 


\section{Atividades não-agrícolas e desigualdade de renda no meio rural}

A imagem tradicional de desenvolvimento do meio rural, nos chamados países emergentes, tem sido a de associá-lo quase exclusivamente à expansão da atividade agrícola. As ocupações RNA ainda hoje são freqüentemente caracterizadas como de baixa produtividade e produtoras de bens de má qualidade, condenadas a desaparecer com o crescimento da economia. O resultado dessa perspectiva é que o governo não precisaria se preocupar em aplicar recursos para promover, no meio rural, atividades fora da agricultura.

Mas com a expansão das atividades RNA, a atual recomendação para as políticas voltadas ao crescimento econômico e ao combate à pobreza no campo tem cada vez mais defendido o abandono do estreito foco no setor agrícola e sua ampliação para as atividades industriais e de serviços. $\mathrm{Na}$ América Latina, por exemplo, as ocupações RNA são consideradas parte da solução do problema da pobreza rural, pelos seguintes motivos:

a) a agricultura tem contribuído cada vez menos para a geração de emprego;

b) o nível de desigualdade de renda na agricultura, atividade em que a maior parte da população rural está ocupada, é alto;

c) as rendas RNA podem complementar o rendimento familiar dos agricultores com pouca ou nenhuma terra;

d) atividades de processamento e de comercialização de alimentos agregam valor e atenuam o efeito da instabilidade dos preços dos produtos agrícolas (Berdegué et alii, 2000, e Lanjouw, 1999).

Particularmente no Brasil, dados recentes publicados na PNAD sobre a agricultura não só mostram uma queda significativa no nível de emprego durante a última década, mesmo com o forte crescimento da produção primária, como também uma desigualdade de renda elevada e resistente à queda (Barros et alii, 2004) ${ }^{3}$. Comparando as informações disponíveis nos trabalhos de Langoni (1973), Fishlow (1973), Hoffmann (1991 e 2001), Corrêa (1998) e Ney e Hoffmann (2003), é possível acompanhar as mudanças no perfil da distribuição dos rendimentos

${ }^{3}$ Entre 1992 e 2001, o número de pessoas ocupadas com atividade principal no setor primário diminuiu em 15\%, significando uma perda de cerca de 2,7 milhões de postos de trabalhos. Como resultado desse declínio, a participação relativa do setor no total de ocupações passou de 29\%, em 1992, para 21\%, em 2001 (ver Barros et alii, 2004). 
agrícolas, desde 1960. Pode-se observar um extraordinário processo de concentração da renda na agricultura, entre 1970 e 1980, o qual elevou o índice de Gini de 0,415 para 0,543, um acréscimo de 31\% (Hoffmann, 1991). Desde então, a desigualdade tem apresentado forte resistência à queda, caracterizando-se por uma enorme proporção da renda apropriada pelos centésimos mais ricos da população (ver Tabela 1) ${ }^{4}$.

Tabela 1. Principais características da distribuição do rendimento de todos os trabalhos das pessoas ocupadas com trabalho principal na agricultura e com renda positiva. Brasil e regiões, 2007

\begin{tabular}{lrrrrrrr}
\hline Estatística & Brasil & \multicolumn{2}{c}{ Norte $^{1}$ Nordeste } & $\begin{array}{r}\text { MG, ES } \\
\text { e RJ }\end{array}$ & SP & Sul & $\begin{array}{r}\text { Centro- } \\
\text { Oeste }\end{array}$ \\
\hline Pessoas (1000) & 9.052 & 766 & 3.836 & 1.485 & 807 & 1.421 & 738 \\
Rdmto. Médio & 555,0 & 533,9 & 309,7 & 589,9 & 790,7 & 865,7 & 926,1 \\
\% da renda & & & & & & & \\
recebida pelos & & & & & & & \\
50\% mais pobres & 17,2 & 22,5 & 18,5 & 22,2 & 24,2 & 16,9 & 18,1 \\
10\% mais ricos & 44,9 & 39,6 & 39,2 & 41,1 & 38,2 & 44,4 & 48,0 \\
5\% mais ricos & 34,2 & 29,6 & 29,8 & 30,8 & 28,5 & 32,3 & 37,8 \\
1\% mais ricos & 15,5 & 14,0 & 15,2 & 10,7 & 10,9 & 14,3 & 19,9 \\
Índice de Gini & 0,538 & 0,455 & 0,496 & 0,467 & 0,423 & 0,538 & 0,539 \\
\hline
\end{tabular}

Fonte: Calculado a partir dos microdados da PNAD de 2007.

${ }^{1}$ Exclusive as áreas rurais de RO, AC, AM, RR, PA e AP.

Vale ressaltar que a desigualdade de renda na agricultura pode estar superestimada, visto que os dados da PNAD, usados nas estimativas, refletem apenas renda monetária e pagamentos em espécie. A produção para o autoconsumo, parte importante da renda do pequeno agricultor, não é considerada. Essa causa de subdeclaração dos rendimentos não chega a ser muito relevante quando se consideram todos os setores da economia. A mais importante deve ser a subdeclaração nos estratos mais altos de renda, que levaria a subestimar as medidas de desigualdade. Mas, quando se analisa apenas o setor agrícola, a situação pode ser inversa, não

${ }^{4}$ Como a PNAD não cobria a área rural da antiga região Norte até 2003, para analisar as mudanças no nível de desigualdade de renda agrícola ao longo do tempo, o ideal é excluir essa área das estimativas que utilizam os dados mais recentes da pesquisa. Após a exclusão, pode se observar que o índice de Gini da distribuição da renda de todos os trabalhos das pessoas ocupadas com rendimento positivo e atividade principal na agricultura fica acima de 0,56 de 1992 a 1997, cai para 0,533 em 1999 e permanece próximo a 0,56 de 2001 a 2006. Em 2007, o índice de Gini da mesma distribuição é igual a 0,544. Se a área rural da antiga região Norte não é excluída, o índice de Gini cai ligeiramente para 0,538 (ver Tabela 1). 
só porque boa parcela da produção dos pequenos agricultores é voltada ao sustento da família, como também porque poucas pessoas têm ganhos muito elevados, se comparados aos dos ocupados na indústria e nos serviços (ver Ney e Hoffmann, 2003).

O estudo do perfil da distribuição da renda das pessoas ocupadas na agricultura, realizado anteriormente, é mais apropriado quando o objetivo da pesquisa é analisar o mercado de trabalho no setor primário. Se o objetivo, porém, é analisar o nível de vida de quem vive no meio rural, a melhor maneira é observar a sua renda domiciliar per capita. Primeiro porque alguns indivíduos recebem rendas não-agrícolas. O rendimento de uma família rural pode incluir ganhos provenientes de atividades agrícolas, industriais e de serviços, de aluguéis, juros e aposentadorias. $\mathrm{O}$ segundo motivo é que a unidade de consumo relevante é a família (ver Hoffmann, 1998). É possível, por exemplo, que o rendimento de um agricultor que reside no campo seja insuficiente para atender às necessidades básicas, mas a renda recebida pelo filho ou esposa em outra atividade aumente substancialmente o bem-estar de toda a família.

As rendas não-agrícolas podem complementar o rendimento familiar dos agricultores com pouca ou nenhuma terra e ainda servir de fonte de recursos financeiros para a compra de insumos necessários para a lavoura, para o enfrentamento dos prejuízos causados por secas, inundações e pragas nas plantações e para amenizar, durante o ano, as fortes flutuações no nível de renda agrícola, que é uma das características da pobreza rural. Atividades de processamento e de comercialização dos alimentos, por sua vez, agregam valor e atenuam o efeito da instabilidade dos preços dos produtos primários. Como conseqüência, a expansão das atividades RNA tenderia a reduzir de forma significativa o nível de desigualdade de renda e pobreza no meio rural.

Reardon et alii (1998), porém, afirmam que as atividades industriais e de serviços, embora possam constituir uma parcela significativa e crescente do ganho monetário das famílias rurais pobres e que sofrem com a escassez de terra, não são uma panacéia antipobreza e nem será um caminho fácil fomentar o desenvolvimento eqüitativo do campo. As ocupações rurais não-agrícolas abrangem uma grande variedade de atividades, com diferenças substanciais de níveis de produtividade, rentabilidade e regularidade na oferta de empregos. Pesquisas recentes mostram uma participação significativa de ocupações mal remuneradas, casuais e com baixo potencial de desenvolvimento, denominadas de ocupações "RNA de 
refúgio" (Berdegué et alii, 2000). Elas compõem principalmente as fontes de renda das famílias pobres e contribuem para complementar o rendimento domiciliar, mas em alguns casos são insuficientes para a superação da pobreza e para o desenvolvimento sustentável das áreas rurais.

Para os autores, o problema é que algumas condições responsáveis pelo nível de desigualdade de renda na agricultura, nos países em desenvolvimento, também afetam a distribuição da renda RNA. No Brasil, em particular, os principais determinantes estruturais da disparidade de renda no setor primário encontrados na literatura são: a distribuição da riqueza, especialmente da posse da terra, a educação e as desigualdades regionais. Entre eles, estudos coincidem em destacar o capital físico como o principal fator responsável pela enorme concentração da renda agrícola ${ }^{5}$. Sua contribuição marginal em equação de rendimentos estimada por Ney e Hoffmann (2003), por exemplo, é de $21,3 \%$, valor muito superior ao da escolaridade $(6,5 \%)$. Em seguida, vem o tempo semanal de trabalho $(8,0 \%)$ e região $(7,0 \%)$. Outros fatores, como discriminação por raça $(0,7 \%)$ e sexo $(0,5 \%)$, poderiam ser citados, mas parecem pouco relevantes na determinação da desigualdade.

Com uma concentração fundiária tão elevada, não surpreende o fato de as estimativas dos efeitos dos determinantes estruturais da distribuição da renda agrícola indicarem o capital físico como o principal fator responsável pela desigualdade de renda na atividade. De acordo com estudo de Ney e Hoffmann (2003), os 1\%, 5\% e 10\% maiores empreendimentos agrícolas no País ficam, respectivamente, com $37,5 \%, 65,8 \%$ e 77,3\% da área total ocupada pelos empreendimentos agrícolas, ao passo que os $50 \%$ menores ocupam apenas $2,4 \%$ da área total. O valor do índice de Gini estimado para a desigualdade na distribuição da posse da terra é de 0,843 .

Uma hipótese comumente encontrada na literatura é que o nível de renda não-agrícola das famílias rurais deve estar negativamente

\footnotetext{
${ }^{5}$ Pesquisadores costumam medir o efeito do capital físico sobre a desigualdade, utilizando apenas a variável posição na ocupação. A hipótese básica é que as diferenças de acesso à propriedade estão fortemente correlacionadas com a discriminação ocupacional: empregado, autônomo e empregador (ver Langoni, 1973). Além dos fatores já considerados usualmente em equações de rendimentos ajustadas para o setor primário, Ney e Hoffmann (2003) estimaram equações de rendimentos para pessoas ocupadas na agricultura em que também incluíram, como variável explanatória, a área dos empreendimentos agrícolas. A contribuição marginal do capital físico, medido pela área e pela posição na ocupação, para soma de quadrados da regressão, é de $21,3 \%$, valor substancialmente maior do que sua contribuição quando medido apenas pela inclusão da posição ocupacional $(13,7 \%)$, como é comum na literatura.
} 
correlacionado com a posse de terra, porque as famílias que sofrem com a escassez de terra têm uma dependência maior do rendimento RNA se comparada à das famílias com grandes propriedades. No entanto, essa não é necessariamente a realidade encontrada nos países em desenvolvimento. Se por um lado a escassez de terra e a insuficiência de renda obtida no setor primário aumentam a necessidade de as famílias ascenderem às atividades RNA, por outro, limitam sua capacidade de ascensão. As desigualdades "no acesso à terra também geram desigualdades de oportunidades no acesso ao emprego não-agrícola, porque a renda agrícola, o uso da terra como garantia de empréstimos e o poder político que a terra oferece podem afetar a participação nas atividades RNA" (Reardon, 1999, p.27).

Lanjouw (1999), por sua vez, destaca o fato de a elevação do nível geral de escolaridade da população rural, nos países em desenvolvimento, ser um fator crucial para a expansão das atividades RNA mais produtivas. Outros trabalhos mostram que o desempenho educacional é uma variável importante para a implantação de atividades de processamento e comercialização de alimentos dentro de empreendimentos que antes só produziam bens primários, para o sucesso dos empreendimentos não-agrícolas e para a obtenção de empregos com maiores salários (Reardon, 1999). Já pesquisas feitas na América Latina coincidem em assinalar que apenas as pessoas com maiores níveis de escolaridade ascendem às ocupações RNA melhor remuneradas (Berdegué et alii, 2000) ${ }^{6}$. Os indivíduos com baixo nível educacional desempenham ocupações pouco rentáveis e casuais.

Conforme pode se observar, nos países ou regiões onde o acesso à educação não está restrito quase exclusivamente às famílias ricas e com mais terra, ele constitui um fator fundamental para a redução do nível de desigualdade de renda nas áreas rurais. Seu efeito equalizador inclusive pode se dar com as ocupações RNA servindo de apoio ou incentivo para atividades agrícolas. $\mathrm{O}$ pequeno agricultor pode investir parte da renda obtida em atividades industriais e de serviços na produção primária. Por outro lado, onde a educação é mal distribuída, as ocupações não-agrícolas podem elevar a desigualdade de renda. Segundo Reardon (1999, p.20), onde "o acesso à educação rural não depende do poder aquisitivo da família, pode se esperar que a educação tenha um maior efeito na redução da desigualdade de renda não-agrícola do que agrícola e que ao mesmo tempo ela reduza as disparidades de renda rural como um todo".

${ }^{6}$ Em Berdegué et alii, (2000, p.1), "emprego inclui tanto o trabalho de autônomo quanto o emprego assalariado". Foi traduzido então "emprego RNA" como ocupação RNA. 
Um problema grave do sistema educacional brasileiro é justamente a existência de uma enorme desigualdade de oportunidade, a qual restringe o acesso da população pobre ao ensino, principalmente de nível médio e superior (ver Filmer e Pritchett, 1998). E essa situação deve ser ainda mais grave no meio rural, onde a incidência da pobreza é muito maior do que nas áreas urbanas e o acesso ao estudo é mais difícil, seja pela entrada precoce no mercado de trabalho, seja por causa da distância das residências em relação às escolas e a dificuldade de transporte (ver Ministério da Educação, 2003). As famílias rurais pobres tendem, assim, a sofrer com a escassez de dois ativos fundamentais na determinação da renda nas áreas onde vivem: terra para plantar e educação, variável que, em qualquer setor de atividade, influencia de forma significativa os níveis de produtividade e renda do trabalho.

\section{Informações sobre a base de dados}

Para analisar a condição de vida das pessoas que vivem no meio rural, será utilizada a renda domiciliar per capita. O rendimento mensal domiciliar é a "Soma dos valores dos rendimentos nominais mensais, dos moradores do domicílio, expressa em reais ( $R$ \$), exclusive das pessoas consideradas na condição do domicílio como pensionistas, empregados domésticos e parentes dos empregados domésticos" (IBGE, 2002, p.88). O valor do rendimento domiciliar per capita foi então obtido dividindo-se o valor do rendimento mensal domiciliar pelo número de moradores do domicílio, classificados como pessoa de referência, cônjuge, filhos, outros parentes e agregados.

Embora as informações sobre renda fornecidas no censo sejam reconhecidamente de boa qualidade, elas apresentam algumas limitações que precisam ser consideradas nas análises dos resultados obtidos nas estimativas:

a) os dados sobre rendimento captam apenas o valor da renda monetária e do pagamento em espécie. Não informam o valor da produção para o autoconsumo e nem a parcela do pagamento efetuada em benefícios (como tíquete alimentação e transporte), que podem representar uma parcela significativa da renda real dos pequenos produtores rurais e empregados, tendendo a subestimar principalmente o ganho dos mais pobres e a ocasionar a superestimação do nível de desigualdade; 
b) outra causa de subestimação da renda é a subdeclaração dos ganhos mais elevados. Para Hoffmann (2000), essa é a principal fonte da subestimação da renda, fazendo com que o nível de desigualdade da distribuição da renda em todo País seja subestimado. Porém, no meio rural, que é o principal objeto deste estudo, considera-se o resultado duvidoso, por conta da participação significativa da produção para o autoconsumo na renda real dos mais pobres;

c) a coleta das informações tem como base a semana que vai do dia 23 a 29 de julho de 2000 . No caso de rendimentos variáveis, procura-se obter o seu valor médio mensal, mas é óbvia a dificuldade de captar o rendimento médio na grande variedade de atividades agrícolas existentes ao longo do ano no País.

Apesar das limitações dos dados, o Censo Demográfico 2000 fornece números importantes para o estudo socioeconômico da população brasileira, particularmente sobre educação e renda (Corrêa, 1998). As restrições devem ficar registradas apenas para que sejam tomados os devidos cuidados na análise dos resultados. Conforme poderá ser observado, elas não chegam a comprometer as conclusões desenvolvidas ao longo do texto.

Neste estudo, serão utilizados os dados individuais (microdados) do censo de 2000 para as pessoas residentes em domicílio particular permanente, excluindo aquelas cuja condição no domicílio é de pensionista, empregado doméstico ou parente de empregado doméstico. Como o objeto principal deste estudo é a população rural, optou-se por excluir da amostra todos os que moravam em domicílio particular improvisado ou coletivo. A localização da moradia de uma parte significativa desse grupo pode ser apenas casual e temporária, como parece ser o caso de quem vive em hotéis, presídios, quartéis, hospitais, orfanatos, trailers, barracas, tendas, e unidades não-residenciais (lojas, fábricas, etc.) sem dependência destinada exclusivamente à moradia.

São encontradas na literatura críticas à forma de delimitação das áreas oficialmente rurais e urbanas do Brasil, a qual diverge da prevalecente na grande maioria dos países e em todos aqueles de importância econômica igual ou superior à nacional. Na maioria dos países, os critérios utilizados para a demarcação são o número de habitantes da localidade, sua densidade populacional, ou a combinação das duas variáveis. A Itália, Espanha, Portugal e Grécia, por exemplo, definem como rural os assentamentos que reúnem em habitações contíguas até no máximo 10 
mil habitantes (Abramovay, 2003). No Brasil, ao contrário, se usa o critério da delimitação administrativa, que classifica como área urbana toda sede de município e de distrito, independente de seu tamanho e características socioeconômicas (Veiga, 2003). Todo o resto compõe as áreas rurais.

O resultado é que as sedes e distritos (vilas) de qualquer um dos 3.771 municípios com população urbana inferior a 10 mil pessoas, por exemplo, são consideradas zona urbana nos dados do IBGE, com estatuto legal de cidade igual ao atribuído às grandes cidades como São Paulo, Rio de Janeiro, Salvador, entre outras. Se fosse adotado o limite de 20 mil habitantes, parâmetro freqüente em organizações internacionais, seria rural toda a população urbana dos 4.591 municípios que estão abaixo desse patamar populacional. Para Veiga (2003) e Abramovay (2003), o surgimento de cidades de tamanho irrisório gera a idéia equivocada de que o nível de urbanização no Brasil teria atingido aproximadamente $81 \%$ da população no ano 2000.

Para este trabalho, foi decidido, então, adotar uma forma de delimitação do espaço rural-urbano diferente da oficial, em que foram combinados três critérios de demarcação: delimitação administrativa, contingente populacional e densidade demográfica. Primeiro classificar-se-á como população rural todas as pessoas cuja situação do domicílio está fora das áreas oficialmente definidas como urbanas no País, independente do tamanho da cidade que circunscreve. Ou seja, as áreas rurais no censo também serão aqui denominadas rurais. Nelas residem cerca de 31,4 milhões de pessoas.

Mas também será considerada rural parte da população oficialmente definida como urbana. Nos casos em que a população urbana do município é inferior a 20 mil habitantes, ela será considerada rural, exceto se a densidade populacional do município ultrapassar o limite de 60 $\mathrm{hab} / \mathrm{km}^{2}$. O espaço rural incluirá, portanto, parte das chamadas "cidades" no País, abrindo a possibilidade de se estudar algo que é uma contradição nos termos: as "cidades rurais" (Abramovay, 2003). O critério da densidade foi examinado porque uma característica fundamental das áreas rurais é a rarefação populacional e existem municípios com poucos habitantes e alta densidade demográfica. O limite de $60 \mathrm{hab} / \mathrm{km}^{2}$ fixado está abaixo do valor encontrado no estrato de municípios com população oficial urbana de 100.000 a 149.999 habitantes $\left(72,0 \mathrm{hab} / \mathrm{km}^{2}\right)$, que já indicaria um razoável grau de urbanização.

Para o cálculo da densidade populacional nos 5.507 municípios existentes por ocasião do Censo Demográfico de 2000, foi necessário obter a 
área de cada município. Para 5.435 municípios, foi utilizada a área do quadro territorial vigente em $1^{1}$ de janeiro de 2001, homologado no Diário Oficial da União de 11 de outubro de 2002. Para os demais 72 municípios, foram usadas as áreas publicadas na Sinopse Preliminar do Censo 2000, porque suas dimensões foram reduzidas para a instalação de 53 novos municípios em 2001. Entre os municípios instalados, vale ressaltar, 52 tinham menos de 20 mil habitantes, 48 menos de 10 mil e 47 menos de 5 mil residentes. Pelo critério da delimitação administrativa, a população das sedes municipais e distritais criadas pelas novas prefeituras será classificada, no próximo censo, como urbana, independentemente de seu contingente populacional.

Essa metodologia aumentou a população rural para cerca de 52,6 milhões de pessoas e reduziu o grau de urbanização do País para 68,7\%. Mas o número de pessoas residentes no meio rural pode ainda estar subestimado. A maior parte da população rural continua definida pelo critério da delimitação administrativa, persistindo duas restrições importantes dos dados: a) os espaços rurais e urbanos são demarcados pelos poderes públicos locais, para os quais o resultado fiscal do Imposto Predial e Territorial Urbano (IPTU) pode ser mais importante do que aspectos geográficos e socioeconômicos ${ }^{7}$; ) a extensão de serviços públicos básicos a um pequeno aglomerado populacional tenderá a defini-lo como urbano, mesmo se ele abranger algumas centenas de casas.

Além dos problemas de natureza metodológica, o censo apresenta dados estranhos na cauda inferior e superior da distribuição da renda. Por um lado, existe um número significativo de domicílios em que o valor do rendimento total declarado é nulo. Ele não representaria grave problema se estivesse restrito às famílias com todos os membros desocupados, ou, se tivesse alguém ocupado, fosse em atividade muito mal remunerada. Em boa parte dos casos, porém, no domicílio vive pelo menos um membro empregado como militar do exército, delegado, desembargador, juiz, diretor de empresa, professor do ensino médio, médico, entre outras profissões cuja renda é alta. Por outro lado, há pessoas ocupadas em atividades de baixa remuneração, como de higiene, garçom, marceneiro e vigia, que informaram renda muito elevada, algumas até mesmo acima de R\$ 100.000 por mês, colocando novamente em dúvida se o valor do rendimento declarado corresponde ao recebido.

${ }^{7}$ Enquanto o Imposto Territorial Rural (ITR) é recolhido pela União, o IPTU é exclusivamente municipal, o que estimula a expansão do perímetro urbano pelos poderes públicos locais. 
A fim de contornar os dois problemas e obter informações mais coerentes sobre as características da distribuição da renda, foram excluídas da amostra as pessoas com renda domiciliar per capita igual a zero e as com valor maior do que $\mathrm{R} \$ 30.000$. Pela Tabela 2, pode ser observada a evolução da amostra da população rural e urbana, em que o meio urbano é classificado em três tipos de cidades: $a$ ) cidades pequenas, nos casos em que a população oficialmente urbana do município não é considerada rural e tem no máximo 99.999 habitantes ${ }^{8}$; b) cidade média, quando a população urbana do município é de 100.000 a 299.999 pessoas; e c) cidade grande, para população urbana a partir de 300.000 pessoas.

A decisão de excluir alguns indivíduos situados na cauda inferior e superior da distribuição da renda elimina boa parte das pessoas pobres e muito ricas, tendendo a subestimar as medidas de desigualdade da distribuição dos rendimentos. Sua inclusão, no entanto, teria o efeito contrário e contribuiria para a superestimação do nível de desigualdade, uma vez que algumas famílias com rendimento não declarado no censo, particularmente as que vivem da produção para o autoconsumo, seriam consideradas sem renda, e outras com rendimento relativamente baixo teriam sua renda superdeclarada.

Tabela 2. Evolução da população rural e urbana após o uso cumulativo das restrições ${ }^{1}$. Brasil, 2000

\begin{tabular}{lrrrrr}
\hline \multirow{2}{*}{ Estatísticas } & \multicolumn{3}{c}{ População rural } & \multicolumn{3}{c}{ População urbana de cidades } \\
& Oficial & Cidades & Pequenas & Médias & Grandes \\
\hline População total & 31.947 .618 & 21.417 .441 & 35.148 .218 & 24.043 .559 & 57.316 .019 \\
& {$[4.872 .096]$} & {$[3.407 .101]$} & {$[3.769 .884]$} & {$[2.432 .431]$} & {$[5.792 .900]$} \\
Exclusive domicílios & 31.471 .905 & 21.234 .680 & 34.907 .824 & 23.902 .644 & 56.933 .440 \\
improvisados e coletivos & {$[4.801 .335]$} & {$[3.377 .537]$} & {$[3.744 .048]$} & {$[2.418 .200]$} & {$[5.754 .507]$} \\
Exclusive pensionistas e & 31.434 .287 & 21.181 .770 & 34.810 .512 & 23.830 .789 & 56.581 .218 \\
empregados domésticos & {$[4.795 .726]$} & {$[3.369 .627]$} & {$[3.733 .841]$} & {$[2.410 .923]$} & {$[5.719 .416]$} \\
Exclusive domicílios com & 28.622 .616 & 20.328 .020 & 33.649 .807 & 23.049 .472 & 54.742 .323 \\
rendimento igual a zero & {$[4.372 .604]$} & {$[3.236 .226]$} & {$[3.606 .884]$} & {$[2.331 .583]$} & {$[5.532 .267]$} \\
Exclusive domicílios com & 28.621 .958 & 20.327 .205 & 33.647 .917 & 23.048 .023 & 54.735 .603 \\
renda domiciliar per & {$[4.372 .518]$} & {$[3.236 .106]$} & {$[3.606 .685]$} & {$[2.331 .429]$} & {$[5.531 .585]$} \\
capita > 30.000 & & & & &
\end{tabular}

Fonte: Elaboração dos autores.

${ }^{1}$ Os valores entre colchetes se referem ao tamanho da amostra. Os demais representam a estimativa da população, obtida por meio do fator de expansão.

${ }^{8}$ Como foi anteriormente visto, toda a população oficialmente urbana dos municípios inferior a 20 mil habitantes foi considerada rural, exceto quando a densidade populacional do município está acima do limite de $60 \mathrm{hab} / \mathrm{km}^{2}$. 


\section{Desigualdade, escolaridade e renda no meio rural brasileiro}

Na Tabela 3, são apresentados o perfil educacional e o nível de renda da população, conforme a nova classificação da situação do domicílio (rural e urbano) adotada nesta pesquisa e três tamanhos de cidades urbanas. Especificamente no que se refere às estimativas sobre educação, foram excluídas as pessoas com menos de 25 anos de idade, sem informação sobre o nível de escolaridade no censo, ou que informaram ter concluído apenas o curso de alfabetização de adultos. Durante todo este item, as mesmas exclusões serão realizadas sempre que os cálculos envolverem a variável educação.

Conforme se pode observar, os níveis de escolaridade e renda no meio rural brasileiro são bem menores do que no meio urbano. Enquanto nas áreas urbanas o rendimento médio está estimado em $\mathrm{R} \$ 377,10$, nas áreas rurais o valor é de $\mathrm{R} \$ 148,70$. Do total de pessoas com 25 anos ou mais de idade que vivem no meio rural, por sua vez, $26,3 \%$ têm escolaridade inferior a um ano e $46,7 \%$ apenas o ensino primário. Quase $75 \%$ da população adulta, portanto, sequer tem o primeiro ano do antigo ensino ginasial. No meio urbano, o nível de escolaridade das pessoas é bem mais alto e heterogêneo.

Tabela 3. Nível de escolaridade ${ }^{1}$ e renda das pessoas, conforme situação de domicílio e tamanhos das cidades. Brasil, 2000

\begin{tabular}{|c|c|c|c|c|c|c|c|c|c|c|c|}
\hline \multirow{2}{*}{ Área } & \multirow{2}{*}{$\begin{array}{l}\text { Renda } \\
\text { Média }\end{array}$} & \multirow{2}{*}{$\begin{array}{l}\text { Escol. } \\
\text { Média }\end{array}$} & \multirow{2}{*}{$\mathrm{S}_{\mathrm{esc}^{2}}$} & \multicolumn{8}{|c|}{$\%$ com escolaridade } \\
\hline & & & & $<1$ & 1 a 3 & 4 & 5 a 7 & 8 & 9 a 10 & 11 & $\geq 12$ \\
\hline rasil & 307,4 & 6,0 & 4,6 & 14,2 & 17,7 & 18,2 & 12,5 & 9,1 & 3,9 & 14,8 & 9,6 \\
\hline ural & 148,7 & 3,7 & 3,7 & 26,3 & 26,5 & 20,2 & 10,0 & 5,2 & 2,1 & 7,2 & 2,6 \\
\hline Oficial & 117,1 & 3,0 & 3,1 & 30,4 & 29,4 & 21,2 & 8,6 & 4,2 & 1,4 & 3,8 & 1, \\
\hline Cidades & 193,1 & 4,7 & 4,1 & 20,8 & 22,7 & 19,0 & 11,8 & 6,6 & 3,0 & 11,6 & 4, \\
\hline Urbano & 377,1 & 6,9 & 4,6 & 9,5 & 14,3 & 17,4 & 13,5 & 10,6 & 4,7 & 17,7 & 12 , \\
\hline $\begin{array}{l}\text { Cidades } \\
\text { pequenas }\end{array}$ & 260,1 & 5,7 & 4,3 & 14,2 & 18,6 & 19,5 & 13,8 & 8,8 & 3,9 & 13,8 & 7 \\
\hline $\begin{array}{l}\text { Cidades } \\
\text { médias }\end{array}$ & 318,8 & 6,5 & 4 & 9,8 & 15,2 & 18,6 & 15,0 & 11,0 & 4,7 & 16,2 & 9 \\
\hline $\begin{array}{l}\text { Cidades } \\
\text { grandes }\end{array}$ & 473,6 & 7,7 & 4,6 & 6,7 & 11,4 & 15,7 & 12,8 & 11,4 & 5,1 & 20,6 & 16,4 \\
\hline
\end{tabular}

Fontes: Elaboração dos autores.

${ }^{1}$ Os dados sobre escolaridade abrangem apenas as pessoas com 25 anos ou mais de idade, excluindo quem não tem informação sobre nível de escolaridade, ou que informou ter concluído apenas o curso de alfabetização de adultos.

${ }^{2} \mathrm{~S}_{\text {esc }}$ é o valor do desvio padrão da escolaridade. 
Com uma mão-de-obra menos qualificada e mais homogênea, a tendência seria que a renda média rural fosse mais baixa, mas que a desigualdade de rendimentos também fosse menor do que a urbana se a educação fosse o único determinante importante da renda. Algo que não acontece. Se a desigualdade de renda rural medida pelo índice de Gini é ligeiramente inferior à urbana, quando medida pelo índice $\mathrm{T}$ de Theil, ela se torna maior (Tabela 4). A diferença ocorre porque o índice de Gini tem maior sensibilidade a transferências regressivas em torno das medidas de tendência central, como moda e mediana. $\mathrm{O}$ índice $\mathrm{T}$ de Theil, ao contrário, é mais sensível a modificações na cauda superior da distribuição da renda e, nesse estrato, a concentração dos rendimentos é maior no meio rural, onde a proporção da renda total apropriada pelo centésimo mais ricos da população $(17,1 \%)$ é substancialmente superior à parcela dos $50 \%$ mais pobres $(13,4 \%)$.

Tabela 4. Principais características da distribuição do rendimento domiciliar per capita no meio rural e urbano. Brasil, 2000

\begin{tabular}{lrrrrrrrr}
\hline \multirow{2}{*}{ Estatística } & Brasil & \multicolumn{3}{c}{ População rural } & \multicolumn{3}{c}{ População urbana de cidades } \\
\cline { 2 - 9 } & & Total & Oficial Cidades & Total Pequenas & Médias & Grandes \\
\hline Pessoas (1000) & 160.381 & 48.949 & 28.622 & 20.327 & 111.432 & 33.648 & 23.048 & 54.736 \\
Rdmto. Médio & 307,4 & 148,7 & 117,1 & 193,1 & 377,1 & 260,1 & 318,8 & 473,6 \\
\% da renda & & & & & & & & \\
recebida pelos & & & & & & & & \\
40\% mais pobres & 7,4 & 8,8 & 9,2 & 9,3 & 8,2 & 9,4 & 9,7 & 7,8 \\
50\% mais pobres & 11,4 & 13,4 & 14,0 & 14,0 & 12,4 & 14,2 & 14,5 & 11,9 \\
10\% mais ricos & 50,8 & 47,7 & 46,3 & 47,1 & 48,6 & 45,9 & 45,2 & 48,2 \\
5\% mais ricos & 37,1 & 35,7 & 34,7 & 34,8 & 34,9 & 33,2 & 32,4 & 33,9 \\
1\% mais ricos & 15,6 & 17,1 & 17,2 & 16,0 & 14,3 & 14,4 & 13,7 & 13,3 \\
Índice de Gini & 0,624 & 0,589 & 0,576 & 0,578 & 0,602 & 0,572 & 0,565 & 0,606 \\
T de Theil & 0,820 & 0,783 & 0,764 & 0,740 & 0,748 & 0,690 & 0,666 & 0,737 \\
\hline
\end{tabular}

Fonte: Elaboração dos autores.

Nas áreas rurais, o 9o decil da distribuição do rendimento é $\mathrm{R} \$ 290,00$, valor inferior a dois salários mínimos da semana de referência do censo ( $\mathrm{R} \$ 151,00)$. Quem tem renda domiciliar per capita igual a dois salários mínimos, portanto, está entre os $10 \%$ mais ricos, que se apropriam de cerca de 47,7\% da renda rural total. Observa-se, também, que há uma grande desigualdade entre o rendimento das pessoas pertencentes ao 
décimo mais rico. O rendimento médio nesse estrato é de $\mathrm{R} \$ 709,30$, valor 2,4 vezes maior do que o 90 percentil (R\$290,00) e 1,5 vez superior ao 95응 percentil ( $\mathrm{R} \$ 458,30)$.

Com um nível de heterogeneidade educacional mais baixo, a enorme concentração da renda no meio rural surpreenderia se não fosse a estrutura fundiária brasileira. Entre os fatores determinantes das disparidades de renda em todo o País, a educação tem sido apontada, desde o início dos anos 70, como o mais relevante, e a democratização do acesso ao ensino como algo fundamental para a redução da desigualdade. Mas, no meio rural, a reforma agrária adquire o status de principal política distributiva, por causa da enorme concentração fundiária, que tem um efeito muito mais forte nas disparidades de renda agrícola do que a escolaridade. O problema é que, ao analisar um instrumento de política, é necessário também considerar sua eficiência. $O$ fato de uma variável ser importante para explicar a desigualdade é condição necessária, mas não suficiente para que ela seja o foco das ações públicas.

Embora a menor influência da educação na desigualdade reduza o papel atribuído à política educacional na distribuição da renda agrícola, a democratização do acesso ao ensino é fundamental para o desenvolvimento eqüitativo do meio rural por causa da expansão das atividades não-agrícolas. Em países em desenvolvimento como o Brasil, "a pouca evidência disponível tende a sustentar a hipótese de que os retornos obtidos com a escolaridade são maiores nas atividades não-agrícolas do que nas agrícolas" (Reardon, 1999, p. 19). Além disso, a educação capacita as pessoas, particularmente as mais pobres, a defenderem seus direitos e a participarem de forma mais ativa na vida social e política do País, gerando mudanças institucionais importantes a favor da eqüidade. Nesse contexto, as estatísticas educacionais sobre a população de baixa renda são fundamentais para o estudo da desigualdade.

Conhecidas as características da distribuição da renda, é possível estabelecer uma linha divisória que separa os indivíduos relativamente pobres e ricos e estudar o perfil educacional de cada grupo. Embora seja inevitável algum grau de arbitrariedade na forma como se define a linha divisória, ela pode ser estabelecida utilizando-se uma medida de desigualdade. Qualquer aumento no rendimento de uma pessoa com renda muito baixa reduzirá o valor de uma medida de desigualdade e qualquer acréscimo no rendimento de uma pessoa com renda alta elevará 
o valor da mesma medida. Hoffmann (2005) mostra que há um valor de renda para o qual ocorre a mudança de sinal, que é o limite entre os relativamente pobres e ricos, aqui representado por $\lambda$.

O índice de Gini é a medida de desigualdade sintética mais utilizada em estudos sobre distribuição de renda. Para uma distribuição com índice de Gini igual a $G$, a linha divisória, ou seja, o limite $(\lambda)$ é o percentil de ordem:

$$
\frac{1+G}{2} \times 100
$$

Como o valor do índice de Gini, em todo o Brasil e em cada recorte geográfico aqui realizado, é um pouco menor ou um pouco maior do que 0,60, o limite entre os relativamente pobres e ricos, em qualquer região, está próximo ao valor do 80 percentil: $\mathrm{R} \$ 368,00$ no Brasil, $\mathrm{R} \$ 175,50 \mathrm{em}$ todo o meio rural, $\mathrm{R} \$ 150,00$ no rural oficial, $\mathrm{R} \$ 230,00$ nas cidades rurais, $\mathrm{R} \$ 465,00$ no meio urbano, $\mathrm{R} \$ 320,30$ nas cidades pequenas, $\mathrm{R} \$ 400,00$ nas cidades médias, e R $\$ 600,00$ nas cidades grandes. Será então definido por aproximação, que, em todo o Brasil e em cada situação de domicílio, quem está entre os $20 \%$ mais ricos pertence aos relativamente ricos e que os $80 \%$ mais pobres são os relativamente pobres.

$\mathrm{Na}$ Tabela 5, pode se observar o perfil educacional da população rural adulta conforme três grupos econômicos: o dos mais pobres, o dos pobres intermediários e o dos mais ricos. Em cada situação de domicílio os valores limites das rendas que separam os três grupos foram estabelecidos considerando-se apenas a sua população, e não a de todo o País. O grupo dos mais pobres é uma subdivisão do grupo dos relativamente pobres. Ele abrange apenas quem tem renda inferior ao 40 o percentil ${ }^{9}$. As pessoas do grupo dos mais ricos são as relativamente ricas, ou seja, as que têm renda igual ou maior ao 80 o percentil. O grupo dos pobres intermediários abrange os relativamente pobres que pertencem aos $40 \%$ restantes da população. Para simplificar, ele será chamado de grupo intermediário.

\footnotetext{
${ }_{9}$ Os valores do $40^{\circ}$ percentil nas regiões analisadas são: R\$ 105,50 em todo o Brasil, R\$ 60,00 no meio rural, $R \$ 50,00$ no rural oficial, $R \$ 79,00$ nas cidades rurais, $R \$ 140,40$ no meio urbano, $\mathrm{R} \$ 110,00$ nas cidades urbanas pequenas, $\mathrm{R} \$ 136,00$ nas cidades médias e $\mathrm{R} \$ 166,70$ nas grandes.
} 
Tabela 5. Perfil educacional das pessoas com 25 anos ou mais de idade que residem no meio rural e urbano, conforme três grupos econômicos: o dos mais pobres, o dos pobres intermediários e o dos mais ricos. Brasil, 2000

\begin{tabular}{|c|c|c|c|c|c|c|c|c|c|c|}
\hline & Estrato & $\begin{array}{l}\text { Escol. } \\
\text { Média }\end{array}$ & $<1$ & 1 a 3 & 4 & 5 a 7 & 8 & 9 a 10 & 11 & $\geq 12$ \\
\hline \multirow{3}{*}{ Brasil } & Mais pobres & 3,5 & 25,7 & 27,3 & 18,8 & 13,9 & 6,1 & 2,6 & 5,1 & 0,5 \\
\hline & Intermediários & 5,6 & 12,8 & 17,5 & 20,8 & 14,8 & 10,9 & 4,7 & 15,1 & 3,5 \\
\hline & Mais ricos & 9,8 & 2,6 & 6,3 & 13,0 & 7,0 & 9,8 & 4,3 & 26,1 & 31,0 \\
\hline \multirow{3}{*}{$\begin{array}{l}\text { Todo } \\
\text { Rural }\end{array}$} & Mais pob & 2,3 & 35,7 & 33,7 & 16,9 & 8,2 & 2,7 & 1,0 & 1,7 & 0,1 \\
\hline & Intermediários & 3,3 & 29,2 & 26,8 & 20,7 & 10,5 & 5,0 & 1,9 & 5,3 & 0,6 \\
\hline & Mais ricos & 6,1 & 10,8 & 17,9 & 23,1 & 11,0 & 8,5 & 3,5 & 16,5 & 8,7 \\
\hline \multirow{3}{*}{$\begin{array}{l}\text { Rural } \\
\text { Oficial }\end{array}$} & Mais pol & 2,0 & 38,6 & 35,3 & 16,1 & 6,4 & 2,0 & 0,6 & 0,9 & 0,1 \\
\hline & Interm & 2,8 & 31,3 & 29,6 & 21,5 & 9,2 & 4,0 & 1,3 & 2,9 & 0,3 \\
\hline & Mais ricos & 4,2 & 21,3 & 23,4 & 25,5 & 9,8 & 6,5 & 2,2 & 8,0 & 3,3 \\
\hline \multirow{3}{*}{$\begin{array}{l}\text { Cidades } \\
\text { Rurais }\end{array}$} & Mais & 3,0 & 30,4 & 30,2 & 17,5 & 11,7 & 4,2 & 1,9 & 3,9 & 0,3 \\
\hline & Intermediários & 4,2 & 22,4 & 23,0 & 20,3 & 12,6 & 6,8 & 3,1 & 10,3 & 1,6 \\
\hline & Mais ricos & 7,6 & 6,3 & 12,7 & 18,6 & 10,5 & 9,3 & 4,3 & 23,3 & 15,0 \\
\hline \multirow{3}{*}{$\begin{array}{l}\text { Todo } \\
\text { Urbano }\end{array}$} & Mais & 4,5 & 17,0 & 22,4 & 19,7 & 18,3 & 9,2 & 4,0 & 8,5 & 1,0 \\
\hline & Intermediários & 6,4 & 8,6 & 14,0 & 19,7 & 14,6 & 12,5 & 5,5 & 19,3 & 5,7 \\
\hline & Mais ricos & 10,6 & 1,8 & 4,5 & 10,6 & 5,5 & 9,1 & 4,0 & 26,6 & 37,9 \\
\hline \multirow{3}{*}{$\begin{array}{l}\text { Cidades } \\
\text { Pequenas }\end{array}$} & Mais $p$ & 3,6 & 24,0 & 26,7 & 19,0 & 15,3 & 6,2 & 2,8 & 5,5 & 0,6 \\
\hline & Intermedi & 5,3 & 13,4 & 18,6 & 21,8 & 15,4 & 10,0 & 4,4 & 13,4 & 3,0 \\
\hline & Mais ricos & 8,8 & 3,3 & 8,4 & 16,2 & 9,0 & 10,2 & 4,7 & 25,1 & 23,2 \\
\hline \multirow{3}{*}{$\begin{array}{l}\text { Cidades } \\
\text { Médias }\end{array}$} & Mais pobres & 4,5 & 16,6 & 22,4 & 20,3 & 19,3 & 9,2 & 3,8 & 7,5 & 0,9 \\
\hline & Intermediários & 6,1 & 9,2 & 15,1 & 20,6 & 16,1 & 12,7 & 5,4 & 16,7 & 4,3 \\
\hline & Mais ricos & 9,7 & 2,4 & 6,1 & 12,9 & 7,5 & 10,4 & 4,7 & 26,5 & 29,5 \\
\hline \multirow{3}{*}{$\begin{array}{l}\text { Cidades } \\
\text { Grandes }\end{array}$} & Mais pobres & 5,2 & 12,8 & 19,1 & 19,3 & 19,4 & 11,5 & 5,1 & 11,5 & 1,5 \\
\hline & Intermediários & 7,4 & 5,4 & 10,7 & 17,8 & 13,1 & 13,6 & 6,1 & 24,4 & 9,0 \\
\hline & Mais ricos & 11,5 & 1,2 & 2,9 & 7,9 & 3,8 & 7,8 & 3,3 & 25,9 & 47,1 \\
\hline
\end{tabular}

Fonte: Elaboração dos autores.

Notas: Nas estimativas sobre o Brasil, foi considerado "mais pobres" e "mais ricos" as pessoas que têm, respectivamente, renda menor do que o valor do percentil $40(\mathrm{R} \$ 105,50)$ e maior ou igual ao valor do percentil 80 (R\$ $368,00)$ da distribuição da renda de todo o País. Nas estimativas por região, os limites são definidos considerando-se apenas a distribuição da renda da região: no meio rural, $R$ \$ 60,00 e R \$ 175,50, no rural oficial, $R \$ 50,00$ e $R$ \$ 150,00, nas cidades rurais, $R \$ 79,00$ e $R \$ 230,00$, no meio urbano, $R$ \$140,40 e $R \$ 465,00$, nas cidades pequenas, $R$ \$110,00 e $R$ \$320,30, nas cidades médias, $R$ \$ 136,00 e R \$ 400,00, e nas grandes cidades, $R \$ 166,70$ e R \$ 600,00. O grupo “intermediário" são os $40 \%$ restantes da população. Nota-se que os cortes são definidos com base no universo de todos os indivíduos independentemente de sua idade, embora as análises abranjam apenas quem tem idade a partir de 25 anos.

Os resultados mostram que, em qualquer situação de domicílio, as desigualdades educacionais existentes entre as classes de renda são elevadas (ver Tabela 5). A diferença entre a escolaridade média do grupo dos mais ricos e a dos mais pobres, por exemplo, chega a 6,3 anos, em todo 
o País, 6,1 anos, no meio urbano, e 3,8 anos, no meio rural. Em valor relativo, essas diferenças significam que a escolaridade média dos mais ricos é, em todo o Brasil, 2,8 vezes maior do que a dos mais pobres, 2,7 vezes, no meio rural, e 2,4 vezes, no urbano. Na comparação com a escolaridade média do grupo intermediário, a do mais ricos é 1,8 vez maior, em todo o Brasil e no meio rural, e 1,7 vez, no urbano.

No meio rural, a escolaridade é muito baixa não só no grupo dos mais pobres, em que $35,7 \%$ dos adultos têm menos de um ano de estudo e 69,4\% sequer completaram o antigo primário (1a a 4a série), como também no grupo intermediário, em que $29,2 \%$ não concluíram a 1a série e $56 \%$ sequer terminaram a 4 a série. A baixa escolaridade da grande maioria da população relativamente pobre deve restringir sua participação nas atividades RNA às ocupações menos produtivas e rentáveis, podendo comprometer o desenvolvimento eqüitativo do meio rural. Pode, inclusive, comprometer o sucesso de uma política de reforma agrária. Ainda que o estado consiga provocar uma mudança brusca na estrutura fundiária brasileira distribuindo terra para os mais pobres, boa parte dos empreendimentos agrícolas familiares constituídos, ao sofrerem com a escassez de capital humano, possivelmente não alcançaria o nível de produtividade e renda necessário à expansão da produção agrícola. Desperdiçaria também oportunidades de aumentar a renda por meio de atividades industriais e de serviços, pois a educação é um determinante significativo da diversificação em atividades não-agrícolas.

Em suma, a enorme concentração fundiária e a baixa heterogeneidade educacional reduzem a importância comumente atribuída à educação na redução da desigualdade de renda rural se comparada ao seu papel na distribuição de renda em todo o País. O problema é que, com um nível de escolaridade tão baixo, dificilmente se pode pensar em desenvolvimento rural com eqüidade sem uma política de expansão educacional da população mais pobre, que tende a sofrer com a escassez de dois ativos importantes na determinação de sua renda: terra para plantar e educação.

\section{Educação e desigualdade de renda} nas atividades rurais não-agrícolas

Seguindo a mesma metodologia utilizada por Hoffmann (2000), as equações de rendimento são ajustadas pelo método dos mínimos quadrados ponderados, usando o fator de expansão associado a cada pessoa da amostra 
como fator de ponderação. A variável dependente $(Y)$ é o logaritmo neperiano do rendimento do trabalho principal das pessoas ocupadas. Grande parte das variáveis explanatórias, por sua vez, são variáveis binárias, que assumem o valor 1 se o indivíduo pertence a determinado grupo, ou 0 , caso não pertença. $\mathrm{O}$ uso da função logarítmica se justifica pela forte assimetria da distribuição da renda e/ou pelo fato de os efeitos serem aproximadamente multiplicativos (ou proporcionais à renda).

O modelo geral de regressão é:

$Y_{j}=\alpha+\sum_{i} \beta_{i} X_{i j}+u_{j}$

no qual $\alpha$ e $\beta_{\mathrm{i}}$ são parâmetros e $u_{j}$ são erros aleatórios heterocedásticos com as propriedades usuais.

São consideradas as seguintes variáveis explanatórias:

a) Uma variável binária para sexo, que assume valor 1 para os homens;

b) Quatro variáveis binárias para distinguir cor: branca (tomada como base), indígena, preta, amarela e parda;

c) A idade da pessoa, medida em dezenas de anos, e também o quadrado dessa variável, tendo em vista que $Y$ não varia linearmente com a idade. A idade é medida em dezenas de anos apenas para evitar que os coeficientes sejam muito pequenos. Se os parâmetros para idade e idade ao quadrado forem indicados por $\lambda_{1}$ e $\lambda_{2}$, respectivamente, deve-se ter $\lambda_{1}>0$ e $\lambda_{2}<0$ e então o valor esperado de $Y$ (e do rendimento) será máximo quando a idade da pessoa for igual a: $-\lambda_{1} /\left(2 \lambda_{2}\right)$;

d) Escolaridade, variando de 0 (no caso de pessoa sem instrução ou com menos de um ano de estudo) a 16 (no caso de pessoa com 16 anos de estudo) e assumindo valor 18 para a pessoa com 17 anos ou mais de estudo;

e) O logaritmo do número de horas semanais de trabalho. O coeficiente dessa variável é a elasticidade do rendimento em relação ao tempo semanal de trabalho;

f) Cinco variáveis binárias para distinguir seis posições na ocupação no trabalho principal: empregado sem carteira de trabalho assinada (sendo a base), empregado com carteira de trabalho assinada, conta própria, empregador com um ou dois empregados (pequeno empregador), empregador com três a cinco empregados (médio empregador) e empregador com seis ou mais empregados (grande empregador); 
g) Uma variável binária que assume valor 1 quando a atividade principal é na indústria ou no setor de serviços e valor zero quando ela é na agricultura;

h) Uma variável binária que assume valor 1 quando o domicílio está nas cidades rurais e valor zero quando está nas áreas rurais oficiais;

i) Cinco variáveis binárias para distinguir seis grandes regiões: Nordeste (sendo a base), Norte, Sudeste, excluindo o estado de São Paulo (MG+ES+RJ), estado de São Paulo, Sul e Centro-Oeste;

j) Três variáveis binárias para distinguir quatro tipos de micro ou mesorregiões, onde estão situadas as localidades rurais: essencialmente rurais (tomadas como base), pouco urbanizadas, muito urbanizadas e metropolitanas (ver Quadro 1).

O efeito das disparidades regionais na conformação da renda no País geralmente é captado nas equações de rendimentos por variáveis que representam as unidades da federação e/ou as cinco grandes regiões brasileiras, porque a PNAD, principal fonte de dados utilizada nas pesquisas, não garante a representatividade da amostra para níveis geográficos menores, como micro e mesorregiões. O problema é que as cidades têm enorme capacidade de transformar as economias das localidades de menor contingente populacional. Não é coincidência que a facilidade de acesso a mercados consumidores de importantes centros urbanos representa, em vários países, um determinante significativo do nível de desenvolvimento das localidades rurais (Abramovay, 2003).

Conforme pode se observar no Quadro 1, as micro ou mesorregiões onde estão situadas as localidades rurais foram classificadas por grau de influência urbana: essencialmente rurais (ER), pouco urbanizada (PU), muito urbanizada $(\mathrm{MU})$ e metropolitana (ME). As microrregiões ${ }^{10}$ brasileiras apresentam tamanhos muito diferentes, e em alguns estados sua área média chega a ser substancialmente maior do que a das mesorregiões ${ }^{11}$ de outras unidades da federação. Esse é o caso de todos os estados do Norte e Centro-Oeste e de parte do Nordeste: Maranhão, Piauí e Bahia. Neles a unidade regional desta análise será a microrregião. Nos demais estados do Nordeste, no Sul e no

\footnotetext{
${ }^{10}$ De acordo com o IBGE (2002, p.67), microrregião é o “Conjunto de municípios, contíguos e contidos na mesma Unidade da Federação, agrupados com base em características do quadro natural, da organização da produção e de sua integração".

${ }^{11}$ Mesorregião é o "Conjunto de microrregiões, contíguas e contidas na mesma Unidade da Federação, agrupadas com base no quadro natural, no processo social e na rede de comunicações e de lugares" (IBGE, 2002, p.67).
} 
Sudeste, a unidade escolhida foi a mesorregião. As microrregiões de Brasília e do "Entorno de Brasília" que pertencem, respectivamente, ao Distrito Federal e a Goiás, constituem uma situação específica em que duas microrregiões serão agregadas e analisadas como uma região.

O estudo avaliará, assim, a função socioeconômica das pequenas, médias e grandes cidades para o desenvolvimento do meio rural brasileiro, onde quase a metade das pessoas vive em regiões essencialmente rurais, ou que não têm nenhum município com população urbana maior ou igual a 100 mil habitantes. O tamanho do mercado consumidor e da oferta de bens e serviços, particularmente de escolas e professores qualificados, encontrados em cidades próximas, deve ser um determinante importante do nível de renda (agrícola e não-agrícola), da escolaridade e da desigualdade de rendimentos entre pessoas nas áreas rurais.

Quadro 1. Classificação das micro e mesorregiões ${ }^{1}$ em que estão situadas as localidades rurais, conforme nível de influência urbana. Brasil, 2000

\begin{tabular}{|l|c|c|l|}
\hline Microrregiões & $\begin{array}{c}\text { Número de } \\
\text { Municípios }\end{array}$ & $\begin{array}{c}\text { População } \\
\text { Rural }\end{array}$ & \multicolumn{1}{|c|}{ Descrição } \\
\hline $\begin{array}{l}\text { Essencialmente } \\
\text { rurais }\end{array}$ & 2.237 & 25.026 .431 & $\begin{array}{l}\text { Abrange apenas municípios com população } \\
\text { urbana inferior a 100 mil habitantes. }\end{array}$ \\
\hline $\begin{array}{l}\text { Pouco } \\
\text { urbanizadas }\end{array}$ & 1.755 & 16.136 .963 & $\begin{array}{l}\text { Aquelas aonde a maior população urbana de } \\
\text { um município vai de 100.000 a 299.999 pessoas. }\end{array}$ \\
\hline $\begin{array}{l}\text { Muito } \\
\text { urbanizadas }\end{array}$ & 896 & 6.352 .365 & $\begin{array}{l}\text { Aquelas aonde a maior população urbana } \\
\text { de um município vai de 300.000 a 749.999 } \\
\text { habitantes. }\end{array}$ \\
\hline Metropolitanas & 619 & 5.100 .299 & $\begin{array}{l}\text { São as regiões metropolitanas ou as } \\
\text { regiões que abrangem algum município } \\
\text { com população urbana maior ou igual a } \\
750 \text { mil pessoas. }\end{array}$ \\
\hline
\end{tabular}

Fonte: Elaboração dos autores.

Nota: Nos estados de Rondônia, Acre, Amazonas, Roraima, Pará, Tocantins, Maranhão, Piauí, Bahia, Mato Grosso do Sul, Mato Grosso e Goiás, as regiões são representadas pelas microrregiões. Nos estados do Ceará, Rio Grande do Norte, Paraíba, Pernambuco, Alagoas, Sergipe, Minas Gerais, Espírito Santo, Rio de Janeiro, São Paulo, Paraná, Santa Catarina e Rio Grande do Sul, onde a área média das microrregiões é relativamente pequena, as regiões são representadas pelas mesorregiões. No caso específico das microrregiões de Brasília e "Entorno de Brasília", que pertencem, respectivamente, ao Distrito Federal e a Goiás, elas são consideradas como uma única região.

Nos ajustes das equações de rendimentos, são utilizados apenas os dados individuais do censo para pessoas ocupadas e com informação de valor positivo para a renda do trabalho principal, excluindo os indivíduos com atividade mal definida e sem informação sobre escolaridade e cor. A fim de obter um conjunto de informações mais coerentes e mais 
homogêneas das características do processo da formação da renda do trabalho, também foram excluídas outras observações:

a) os indivíduos com idade superior a 100 anos que, de acordo com os dados do censo, se enquadrariam na categoria de ocupados (ver Tabela 6);

b) como o rendimento do trabalho principal é a variável dependente das equações de renda, para contornar o problema das pessoas ocupadas em atividades de baixa remuneração que informaram rendimento muito elevado, em vez de excluir todos os domicílios com renda per capita superior a $R \$ 30.000$, foram excluídas apenas as pessoas com renda no trabalho principal acima de $\mathrm{R} \$ 80.000$ (ver Tabela 6);

c) as pessoas que freqüentaram apenas o curso de "alfabetização de adultos", porque elas, na variável "anos de estudo", não pertencem a nenhuma das categorias referentes aos anos seqüenciais de escolaridade (ver Tabela 6).

Tabela 6. Evolução da amostra após o uso cumulativo das restrições ${ }^{1}$. Brasil, 2000

\begin{tabular}{lcrr}
\hline \multirow{2}{*}{ Estatísticas } & \multicolumn{3}{c}{ População rural } \\
\cline { 2 - 4 } & \multicolumn{1}{c}{ Total } & \multicolumn{1}{c}{ Oficial } & \multicolumn{1}{c}{ Cidades } \\
\hline Pessoas ocupadas com informação de & 15.833 .546 & 8.491 .501 & 7.342 .045 \\
renda positiva no trabalho principal & {$[2.454 .594]$} & {$[1.280 .659]$} & {$[1.173 .935]$} \\
Exclusive quem tem renda no trabalho & 15.833 .071 & 8.491 .290 & 7.341 .780 \\
principal maior do que R\$ 80.000 & {$[2.454 .523]$} & {$[1.280 .629]$} & {$[1.173 .894]$} \\
Exclusive as pessoas sem informação & 15.351 .671 & 8.215 .963 & 7.135 .707 \\
sobre cor e nível de escolaridade & {$[2.381 .587]$} & {$[1.239 .888]$} & {$[1.141 .699]$} \\
Exclusive quem tem mais de & 15.350 .593 & 8.215 .386 & 7.135 .207 \\
100 anos de idade & {$[2.381 .417]$} & {$[1.239 .801]$} & {$[1.141 .616]$} \\
Exclusive as pessoas com apenas & 15.316 .509 & 8.192 .486 & 7.124 .023 \\
o curso de alfabetização de adultos & {$[2.376 .182]$} & {$[1.236 .360]$} & {$[1.139 .822]$} \\
\hline
\end{tabular}

Fonte: Elaboração dos autores.

${ }^{1}$ Os valores entre colchetes se referem ao tamanho da amostra. Os demais representam a estimativa da população, obtida por meio do fator de expansão.

Quanto à variável educação, vários estudos empíricos mostram que a taxa de retorno para cada ano adicional de estudo não é constante para todas as séries. Primeiro porque existe o chamado "efeito diploma". A conclusão de cada etapa do ensino formal, ou seja, do último ano do ensino fundamental, médio, superior e das pós-graduações fornece evidências adicionais de que o indivíduo tem maior potencial produtivo se comparada à conclusão das respectivas séries iniciais e intermediárias. Segundo porque existe um outro 
efeito que será considerado neste estudo: o "threshold effect", que significa uma mudança na inclinação da função da educação depois de certo nível de escolaridade (Simão, 2004). Uma sociedade, dado seu estágio de desenvolvimento socioeconômico, exige maior ou menor qualificação da sua mão-de-obra. Países com uma indústria forte e de alto padrão tecnológico, por exemplo, requerem trabalhadores com níveis de escolaridade bem mais elevados do que aqueles cuja base da economia ainda é a agricultura.

A Figura 1 mostra os coeficientes estimados para cada ano de escolaridade, utilizando 17 variáveis binárias para distinguir 18 níveis de estudo, em que as pessoas analfabetas ou com menos de 1 ano de estudo são tomadas como base. Nota-se que, até os 10 anos de escolaridade, a taxa de retorno para cada ano adicional de estudo é substancialmente inferior a dos níveis de escolaridade posteriores, quando a declividade da função da educação se torna bem maior. O ganho de renda gerado pela conclusão de apenas o último ano do ensino médio e primeiro ano do ensino superior (dois anos de estudo), em qualquer região rural, por exemplo, é semelhante ao ganho gerado pela conclusão de todas as séries do ensino fundamental e dos dois primeiros anos do ensino médio (dez anos de estudo).

Figura 1. Coeficientes estimados para as variáveis binárias "anos de escolaridade", tomando as pessoas analfabetas ou com menos de 1 ano de estudo como base. Regiões rurais, 2000

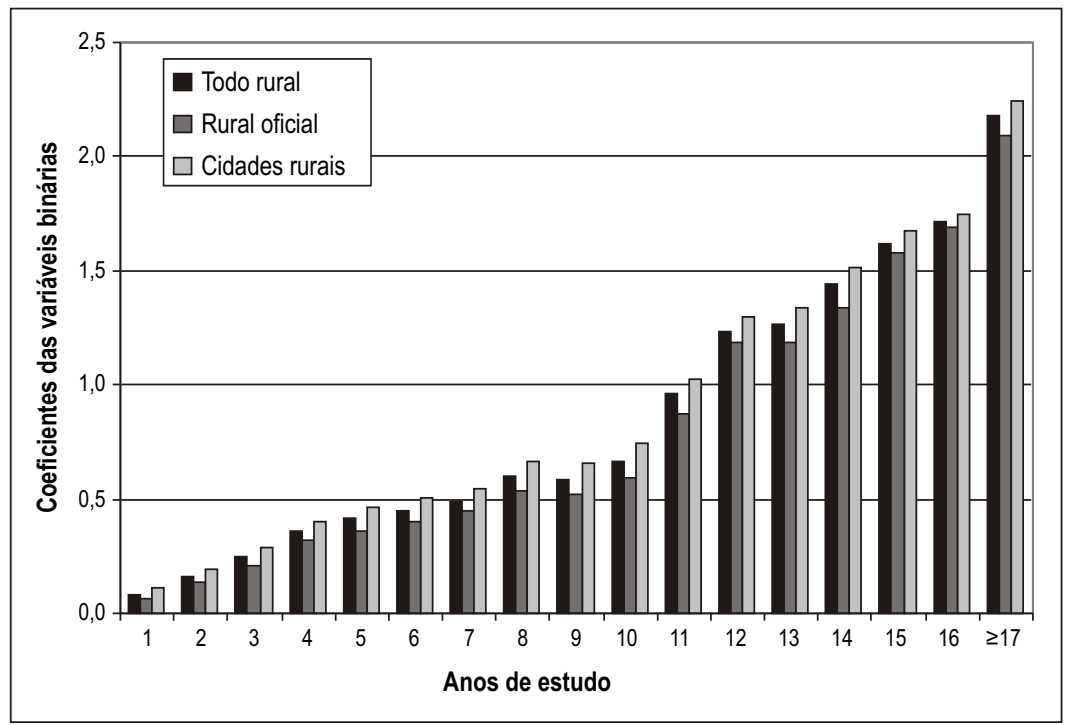

Fonte: Elaboração dos autores. 
Como o efeito da educação na renda se torna mais intenso depois do $10^{\circ}$ ano de estudo, foi incluída na equação de rendimentos uma variável binária $\left(Z_{1}\right)$ para captar essa mudança da influência da educação no rendimento:

k) uma variável binária $\left(Z_{1}\right)$ que assume valor 0 para quem tem escolaridade menor ou igual a 10 anos e valor 1 para quem tem escolaridade maior do que 10 anos. Além da própria escolaridade (Esc), inclui-se, na equação de regressão, a variável $Z_{1}(E s c-10)$. Se os coeficientes dessas duas variáveis forem $\beta_{1}$ e $\beta_{2}$, respectivamente, então $\beta_{1}$ é o efeito de cada ano adicional de escolaridade até os 10 anos de escolaridade e, a partir desse ponto o efeito passa a ser $\beta_{1}+\beta_{2}$. O modelo corresponde a pressupor que a relação entre $Y$ e Esc tem a forma de uma poligonal com vértice na abscissa $E s c=10$.

A Tabela 7 apresenta os resultados das equações estimadas para o meio rural como um todo, o rural oficial e as cidades rurais. A partir do coeficiente estimado de cada variável binária utilizada na regressão, é possível se obter a diferença percentual entre o rendimento esperado de uma dada categoria e a renda esperada da categoria base, depois de descontados os efeitos de todas as outras variáveis explanatórias incluídas na regressão. Sendo o coeficiente da variável binária expresso por $b$, a variação percentual no rendimento esperado das pessoas será dado por: $100[\exp (b)-1] \%$. Quando a variável é a escolaridade, a mesma fórmula é usada para calcular o acréscimo percentual na renda esperada produzido por cada ano adicional de estudo, ou seja, a taxa de retorno do fator.

Os coeficientes da escolaridade mostram novamente que o efeito da educação no logaritmo da renda se torna muito mais intenso nos níveis mais elevados de escolaridade. Até 10 anos de estudo, a taxa de retorno para cada ano adicional de educação formal é de 7,3\% no meio rural como um todo, de 6,6\% no rural oficial, e de 7,9\% nas cidades rurais. A partir dos 10 anos de estudo, as mesmas taxas sobem, nas três regiões rurais, para cerca de $19 \%$. Se não tivéssemos utilizado a variável binária $Z_{1}$ para captar o "threshold effect", o acréscimo percentual na renda esperada produzido por cada ano adicional de estudo seria de 9,2\% em todo rural, $8 \%$, no rural oficial, e de $10,1 \%$ nas cidades rurais. 
Tabela 7. Equações de rendimentos ajustadas para pessoas ocupadas no meio rural, considerando a renda do trabalho principal. Regiões rurais, 2000

\begin{tabular}{|c|c|c|c|c|c|c|}
\hline \multirow[b]{2}{*}{ Variável } & \multicolumn{2}{|c|}{ Todo rural } & \multicolumn{2}{|c|}{ Rural oficial } & \multicolumn{2}{|c|}{ Cidades rurais } \\
\hline & $\begin{array}{l}\text { Coefi- } \\
\text { cientes }\end{array}$ & $\begin{array}{c}\text { Renda } \\
\text { esperada1 }\end{array}$ & $\begin{array}{l}\text { Coefi- } \\
\text { cientes }\end{array}$ & $\begin{array}{c}\text { Renda } \\
\text { Esperada1 }^{1}\end{array}$ & $\begin{array}{c}\text { Coefi- } \\
\text { cientes }\end{array}$ & $\begin{array}{c}\text { Renda } \\
\text { esperada }{ }^{1}\end{array}$ \\
\hline Constante & 1,3655 & - & 1,6574 & - & 1,1329 & - \\
\hline Sexo masculino & 0,4335 & 54,3 & 0,4197 & 52,2 & 0,4366 & 54,7 \\
\hline Idade/10 & 0,6023 & - & 0,4742 & - & 0,7472 & - \\
\hline$(\text { Idade } / 10)^{2}$ & $-0,0586$ & - & $-0,0449$ & - & $-0,0748$ & - \\
\hline Escolaridade $\leq 10$ anos $\left(b_{1}\right)$ & 0,0706 & 7,3 & 0,0640 & 6,6 & 0,0757 & 7,9 \\
\hline $\begin{array}{l}\text { Escolaridade }>10 \text { anos } \\
\left(b_{1}+b_{2}\right)\end{array}$ & 0,1748 & 19,1 & 0,1766 & 19,3 & 0,1718 & 18,7 \\
\hline Cor: Preta & $-0,1528$ & $-14,2$ & $-0,1424$ & $-13,3$ & $-0,1658$ & $-15,3$ \\
\hline Amarela & 0,1658 & 18,0 & 0,1936 & 21,4 & 0,1312 & 14,0 \\
\hline Parda & $-0,1163$ & $-11,0$ & $-0,1155$ & $-10,9$ & $-0,1187$ & $-11,2$ \\
\hline Indígena & $-0,1383$ & $-12,9$ & $-0,1773$ & $-16,2$ & $-0,0852$ & $-8,2$ \\
\hline Log (horas trab./semana) & 0,3918 & - & 0,3831 & - & 0,3959 & - \\
\hline Grande Região: Norte & 0,4216 & 52,4 & 0,4788 & 61,4 & 0,3625 & 43,7 \\
\hline $\mathrm{MG}+\mathrm{ES}+\mathrm{RJ}$ & 0,2941 & 34,2 & 0,3220 & 38,0 & 0,2555 & 29,1 \\
\hline SP & 0,4511 & 57,0 & 0,5286 & 69,7 & 0,3627 & 43,7 \\
\hline Sul & 0,3278 & 38,8 & 0,4020 & 49,5 & 0,2621 & 30,0 \\
\hline Centro-Oeste & 0,4600 & 58,4 & 0,5692 & 76,7 & 0,3713 & 45,0 \\
\hline \multicolumn{7}{|l|}{ Posição na ocupação: } \\
\hline $\begin{array}{l}\text { Empregado com } \\
\text { carteira assinada }\end{array}$ & 0,2638 & 30,2 & 0,2797 & 32,3 & 0,2465 & 28,0 \\
\hline Conta própria & 0,1270 & 13,5 & 0,0746 & 7,7 & 0,2061 & 22,9 \\
\hline Pequeno empregador ${ }^{2}$ & 0,9660 & 162,7 & 0,9202 & 151,0 & 0,9853 & 167,9 \\
\hline Médio empregador ${ }^{3}$ & 1,2715 & 256,6 & 1,2359 & 244,1 & 1,2855 & 261,7 \\
\hline Grande empregador ${ }^{4}$ & 1,5245 & 359,3 & 1,5279 & 360,8 & 1,5194 & 357,0 \\
\hline \multicolumn{7}{|l|}{ Microrregião: } \\
\hline Pouco urbanizada & 0,0347 & 3,5 & 0,0486 & 5,0 & 0,0183 & 1,8 \\
\hline Muito urbanizada & 0,0841 & 8,8 & 0,1088 & 11,5 & 0,0612 & 6,3 \\
\hline Metropolitana & 0,1412 & 15,2 & 0,1536 & 16,6 & 0,0731 & 7,6 \\
\hline Cidade rural & 0,0114 & 1,1 & - & - & - & - \\
\hline Atividades não-agrícolas & 0,2295 & 25,8 & 0,2329 & 26,2 & 0,1861 & 20,4 \\
\hline Número de observações & 2.376 .182 & - & 1.236 .360 & - & 1.139 .822 & - \\
\hline$\underline{\mathrm{R}^{2}}$ & 0,444 & - & 0,396 & - & 0,483 & - \\
\hline
\end{tabular}

Fonte: Elaboração dos autores.

${ }^{1}$ Diferença percentual entre os rendimentos estimados da categoria considerada e da categoria tomada como base.

${ }^{2}$ Pequeno empregador é aquele com um ou dois empregados.

${ }^{3}$ Médio empregador é aquele com três a cinco empregados.

${ }^{4}$ Grande empregador é quem tem seis ou mais empregados. 
Se o efeito do capital humano na renda do trabalho é elevado, o mesmo acontece com o do capital físico. Em todo rural, ser um grande, médio e pequeno empregador significa ter uma renda que tende a ser, respectivamente, $359,3 \%, 256,6 \%$ e $162,7 \%$, superior à renda dos empregados sem carteira de trabalho assinada. No caso dos conta própria, surpreende que o coeficiente seja inferior ao dos empregados com carteira assinada, o que em parte pode ser explicado pela falta de informação no censo demográfico sobre o valor da produção para o autoconsumo. Como ela deve representar uma parcela significativa do rendimento real dos agricultores por conta própria, sua renda estaria mais subestimada do que a dos empregados. Além disso, uma parcela da produção agrícola familiar comumente é comercializada de forma ocasional, como é o caso da venda de um novilho ou de alguns frangos por um pequeno produtor de verduras ou legumes. É provável que ele não informe pelo menos parte do rendimento obtido com esse tipo de venda.

De qualquer forma, os resultados apresentados são suficientemente robustos para reafirmar a enorme importância do capital físico como determinante do rendimento das pessoas ocupadas. A renda esperada dos empregadores é bem maior do que a dos conta própria e empregados, e uma condição fundamental para alguém pertencer àquela posição ocupacional, principalmente à de grande empregador, é possuir uma quantidade relativamente grande de meios de produção, entre eles a terra. Segundo estimativas de Ney e Hoffmann (2003), embora os empregadores representem apenas cerca de $5 \%$ do total de agricultores com renda do trabalho, eles possuem uma área média de cerca de 221,0 ha e ocupam mais da metade da área total ocupada pelos empreendimentos agrícolas no País.

A Tabela 8 registra a contribuição marginal de cada determinante da renda para a explicação das variações no logaritmo do rendimento do trabalho principal da população rural, o que permite avaliar sua importância relativa em cada modelo. As contribuições dos fatores na equação que abrange todo o meio rural são: Sexo, 7,7\%, Cor, 0,7\%, Idade, 11,1\%, Escolaridade, 20,9\% , Horas Semanais de Trabalho, 6,2\% , Posição na Ocupação, 7,4\%, Ramo de Atividade, 2,0\%, Microrregião, 0,3\%, Grande Região, 6,7\%, e Situação de Domicílio (rural oficial ou cidades rurais), $0,0 \%$. 
A educação se destaca como o fator que explica, individualmente, a maior parcela das disparidades de renda do trabalho no meio rural, com efeito substancialmente maior do que o de todos os outros fatores. Em seguida vem a idade, que foi incluída nas regressões com o intuito de captar os ganhos de produtividade e renda associados à experiência adquirida no próprio trabalho, aos treinamentos realizados nas empresas e à realização de cursos fora do ensino formal. Ela também capta simultaneamente o efeito negativo da redução da capacidade de trabalho na renda provocado pelo envelhecimento. Os coeficientes estimados da variável mostram que a relação entre idade e renda é positiva até se chegar a um rendimento máximo esperado aos 51 anos no meio rural como um todo, 53 anos, nas áreas oficialmente rurais do País, e 50 anos, nas cidades rurais (ver Tabela 7). A partir daí a relação se torna negativa.

Tabela 8. Contribuição marginal de cada fator da

Tabela 7 para a soma de quadrados da regressão

\begin{tabular}{lccc}
\hline Variável & Todo rural & Rural oficial & Cidades rurais \\
\hline Sexo & $7,7 \%$ & $7,3 \%$ & $8,2 \%$ \\
Cor & $0,7 \%$ & $0,8 \%$ & $0,7 \%$ \\
Idade & $11,1 \%$ & $8,8 \%$ & $14,4 \%$ \\
Escolaridade & $20,9 \%$ & $14,5 \%$ & $27,4 \%$ \\
Horas trab./semana & $6,2 \%$ & $6,5 \%$ & $6,2 \%$ \\
Posição na ocupação & $7,4 \%$ & $6,5 \%$ & $8,8 \%$ \\
Ramo de atividade & $2,0 \%$ & $2,6 \%$ & $1,0 \%$ \\
Microrregião & $0,3 \%$ & $0,6 \%$ & $0,1 \%$ \\
Grande região & $6,7 \%$ & $10,9 \%$ & $4,0 \%$ \\
Situação de domicílio & $0,0 \%$ & - & - \\
\hline
\end{tabular}

Fonte: Elaboração dos autores.

Nota: A contribuição marginal da localização regional, medida pelas variáveis Grande Região e Microrregião (Mesorregião) é de 7,8\% no meio rural como um todo, 12,8\% nas áreas oficialmente rurais, e de 4,5\% nas cidades rurais.

A localização regional é outro condicionante importante da renda, por causa dos grandes contrastes de desenvolvimento entre regiões. No meio rural oficial, sua contribuição marginal de $12,8 \%$, medida pelas variáveis Grande Região e Microrregião, chega a alcançar um valor bem próximo da contribuição marginal de $14,5 \%$ da escolaridade. Os coeficientes das grandes regiões indicam que, no meio rural como um todo, a renda esperada das pessoas ocupadas na região Norte é $52,4 \%$, em MG+ES+RJ, 
$34,2 \%$, no estado de São Paulo, 57,0\%, na região Sul, 38,8\%, e no Centro-Oeste, $58,4 \%$ maior do que no Nordeste. Já a renda esperada de quem mora nas microrregiões (mesorregiões) metropolitanas é 15,2\% superior à das pessoas residentes nas microrregióes (mesorregiões) essencialmente rurais. Nas regiões muito urbanizadas, a mesma diferença cai para $8,8 \%$.

Embora o capital físico também ocupe lugar de destaque entre os fatores determinantes do rendimento do trabalho no meio rural, a contribuição da educação na conformação da renda é muito maior, o que sugere duas questões chaves para a discussão sobre a elaboração de políticas voltadas à redução das desigualdades de renda nas áreas de menor contingente demográfico do País (ver Tabela 8). A primeira é que as políticas devem considerar não só as ações a favor da reforma agrária, como também a necessidade de se enfrentar um problema estrutural grave: a baixíssima escolaridade da população pobre. Isso não implica, porém, negar a grande importância que a redução da concentração fundiária poderia ter no combate à pobreza e na diminuição das disparidades de rendimentos nas áreas rurais, sobretudo no setor agrícola.

A segunda questão chave é que a expansão das atividades não-agrícolas tende a aumentar o efeito da educação na renda rural. Os resultados acima contrastam com os dados obtidos em equações de rendimentos para pessoas ocupadas exclusivamente em atividades agrícolas, que costumam apontar o capital físico como o principal determinante das desigualdades de rendimentos. Em estudo realizado por Corrêa (1998), a contribuição marginal da variável posição na ocupação para a soma de quadrados da regressão da renda no setor primário é de $20,19 \%$, ao passo que a da escolaridade é de $10,43 \%$. Nas equações estimadas por Hoffmann (2003), as contribuições das duas variáveis são, respectivamente, de $14 \%$ e de 7,4\%. Embora "a educação seja a variável preponderante na explicação da desigualdade de renda em áreas urbanas do Brasil, conforme a maior parte de pesquisas contemporâneas sobre o assunto, no setor agrícola sua importância é inferior àquela definida pela variável posição na ocupação" (Corrêa, 1998, p.151).

A fim de comparar a contribuição marginal da escolaridade e da posição na ocupação para as diferenças individuais de renda nas atividades rurais agrícolas e não-agrícolas, foram ajustadas regressões de rendimentos para pessoas ocupadas dentro de cada um dos dois ramos de 
atividade, utilizando as mesmas variáveis explanatórias definidas anteriormente. Conforme pode se observar na Figura 2, a contribuição marginal da proxy do capital físico no setor primário é superior à do capital humano, embora a diferença existente entre os dois fatores seja menor do que as observadas em outros estudos sobre desigualdades de rendimentos na agricultura (ver Corrêa, 1998, e Ney e Hoffmann, 2003). Já nas atividades não-agrícolas, ao contrário, a influência da escolaridade na distribuição da renda é muito maior do que a da posição na ocupação. Em todo o meio rural, a presença da indústria e do setor de serviços na geração de emprego e renda contribui, assim, claramente para a redução da influência do capital físico e o aumento do efeito da educação na renda captados em equações de rendimentos.

Figura 2. Contribuição marginal da escolaridade e da posição na ocupação em regressões dentro de cada ramo de atividade (em \%). Regiões rurais, 2000

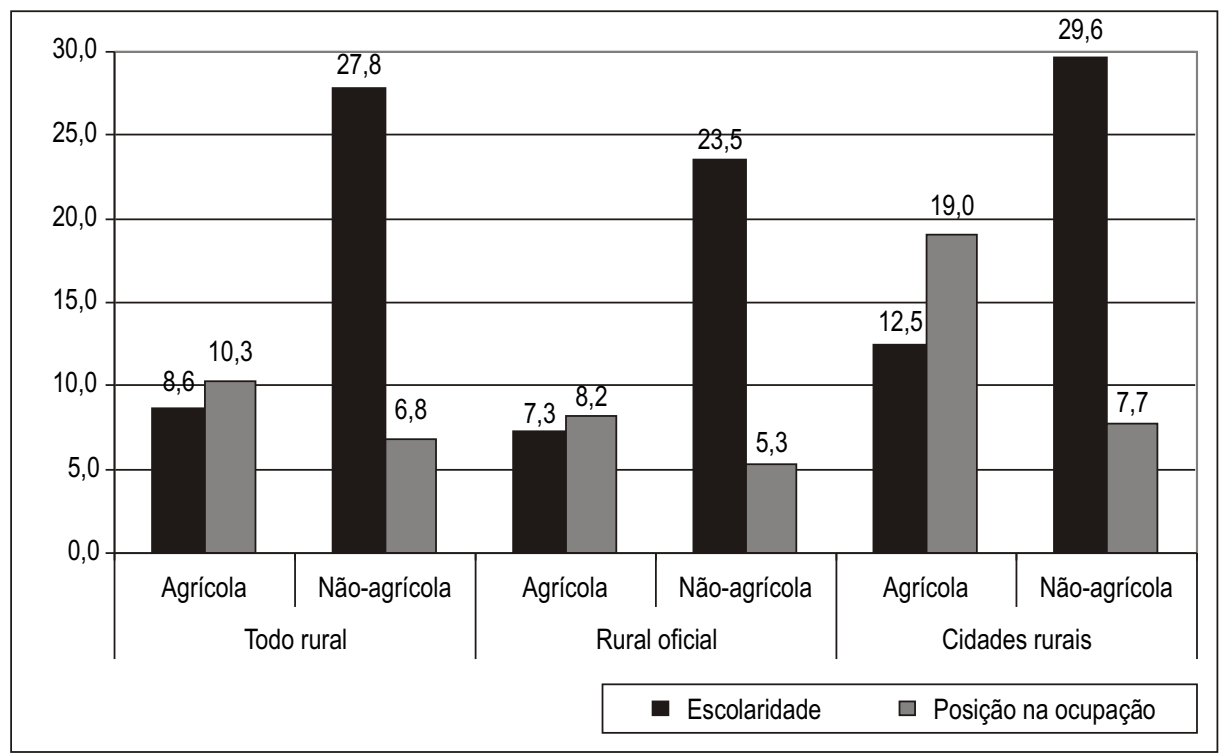

Fonte: Elaboração dos autores.

Se uma variável omitida tem impacto positivo e significativo sobre a renda e está positivamente correlacionada com as variáveis incluídas nas regressões, ocorre uma superestimação dos coeficientes e da contribuição marginal das variáveis incluídas no modelo que estão positivamente relacionadas à omitida. Quanto à educação, há uma possibilidade clara de 
seu efeito na renda pessoal e nas desigualdades de rendimentos estar superestimado, neste estudo, por conta da falta de uma medida mais precisa da dotação de riqueza do que a posição na ocupação, variável que tem relação com o nível de escolaridade das pessoas.

Fortes indícios empíricos podem ser encontrados para a defesa desse argumento. Um microempresário, com um único empregado, vai constar dos dados como empregador, enquanto um executivo e acionista de uma grande companhia aparece como empregado, mesmo tendo muitas ações. Além disso, a contribuição marginal da educação é mais baixa na agricultura do que na indústria e serviços, o que indica um menor efeito da escolaridade na determinação da renda dos indivíduos ocupados no setor primário. Uma explicação alternativa, conforme Hoffmann (2000), seria a posição na ocupação refletir melhor a propriedade do capital físico nas atividades agrícolas do que nas não-agrícolas, por ser o empregador tipicamente o proprietário da terra, o que levaria a superestimar menos a influência do capital humano nos rendimentos pessoais da agricultura.

Por outro lado, a influência do capital físico no rendimento pode estar subestimada porque a concentração dos meios de produção existente dentro de cada categoria ocupacional deve ser significativa e não é captada. No caso da concentração fundiária, por exemplo, o índice de Gini que mede a desigualdade na distribuição da área dos empreendimentos agrícolas exclusivamente dentro da categoria dos empregadores é de 0,769. Entre os conta próprias, ele se torna ainda maior: 0,787 (ver Ney e Hoffmann, 2003).

De qualquer forma, o que se discute é apenas a magnitude do efeito estimado do capital humano e do capital físico na conformação do rendimento do trabalho. Os resultados deste trabalho mostram evidências suficientemente confiáveis para se destacar que a influência da educação na renda não-agrícola e em toda a economia rural é muito maior do que nas atividades agrícolas. Ainda que a taxa de retorno estimada da escolaridade, tanto antes quanto a partir de 10 anos de estudo, seja maior nas atividades não-agrícolas, possivelmente porque a posição na ocupação não reflete tão bem a propriedade de capital quanto no setor primário, a mão-de-obra dos agricultores é bem menos qualificada e mais homogênea do que nos demais setores de atividade (ver Tabela 9). 
Tabela 9. Perfil educacional da população ocupada com renda no trabalho principal e a taxa de retorno da escolaridade, conforme ramo de atividade. Regiões rurais, 2000

\begin{tabular}{|c|c|c|c|c|c|c|c|c|c|c|c|c|}
\hline \multirow[t]{2}{*}{ Estatística } & \multirow{2}{*}{$\begin{array}{l}\text { Escol. } \\
\text { Média }\end{array}$} & \multirow[t]{2}{*}{$S^{1}$} & \multicolumn{8}{|c|}{$\%$ com escolaridade } & \multicolumn{2}{|c|}{$\begin{array}{l}\text { Taxa de } \\
\text { retorno }\end{array}$} \\
\hline & & & $<1$ & 1 a 3 & 4 & 5 a 7 & 8 & 9 a 10 & 11 & $\geq 12$ & $\leq 10$ & $>10$ \\
\hline Todo rural & 4,9 & 3,9 & 15,2 & 23,7 & 19,6 & 14,9 & 7,3 & 4,6 & 11,0 & 3,6 & 7,3 & 19,1 \\
\hline Agrícola & 3,1 & 2,8 & 25,2 & 32,0 & 22,2 & 11,5 & 4,2 & 1,8 & 2,7 & 0,5 & 6,0 & 16,3 \\
\hline Não-agrícola & 6,2 & 4,0 & 8,1 & 17,7 & 17,8 & 17,4 & 9,6 & 6,6 & 17,0 & 5,9 & 7,9 & 18,9 \\
\hline Rural oficial & 3,9 & 3,4 & 20,1 & 28,3 & 21,8 & 13,1 & 6,0 & 3,0 & 6,1 & 1,5 & 6,6 & 19,3 \\
\hline Agrícola & 2,9 & 2,7 & 26,1 & 32,4 & 22,8 & 10,7 & 3,9 & 1,5 & 2,2 & 0,4 & 5,7 & 16,0 \\
\hline Não-agrícola & 5,4 & 3,8 & 10,6 & 21,7 & 20,3 & 17,0 & 9,3 & 5,4 & 12,3 & 3,4 & 7,3 & 19,7 \\
\hline Cidades rurais & 6,1 & 4,1 & 9,6 & 18,4 & 17,1 & 17,0 & 8,9 & 6,4 & 16,7 & 6,1 & 7,9 & 18,7 \\
\hline Agrícola & 3,6 & 3,2 & 22,0 & 30,3 & 20,0 & 14,3 & 5,2 & 2,7 & 4,4 & 1,0 & 6,4 & 15,8 \\
\hline Não-agrícola & 6,7 & 4,1 & 6,6 & 15,6 & 16,4 & 17,6 & 9,7 & 7,2 & 19,6 & 7,3 & 8,1 & 18,6 \\
\hline
\end{tabular}

Fonte: Elaboração dos autores.

${ }^{1}$ Desvio padrão da escolaridade.

Em todo meio rural, do total de indivíduos ocupados na agricultura, mais de $1 / 4$ são analfabetos ou têm escolaridade inferior a 1 ano e cerca de $54 \%$ têm apenas o ensino primário completo ou incompleto. Quase $80 \%$ dos agricultores, portanto, sequer concluíram o primeiro ano do antigo ensino ginasial. Nos outros setores, o desempenho educacional dos trabalhadores é melhor: mais de 55\% terminaram a 5a série, quase $40 \%$ cursaram todo o ensino fundamental e $23 \%$ concluíram o ensino médio.

Dessa forma, a tendência seria de que a expansão da participação do conjunto de atividades industriais e de serviços na geração de renda no meio rural, também observado em outros países em desenvolvimento e já demonstrado por pesquisas feitas com base em dados da PNAD dos anos 80 e 90 no Brasil, esteja associada a uma redução da influência da posse da terra e a um aumento do efeito da educação na renda, nas áreas menos populosas do País.

\section{Conclusão}

Uma explicação chave encontrada na literatura para que as ocupações não-agrícolas, em vez de contribuírem para a redução da desigualdade de renda rural, contribuam para aumentá-la é que as mesmas condições 
responsáveis pela concentração de renda na agricultura também tendem a afetar, com maior ou menor intensidade, a distribuição do rendimento não-agrícola. Não só na agricultura, como também nos outros setores, as famílias mais pobres e com escassez de terra desenvolvem principalmente atividades que exigem pouca qualificação e baixo investimento, ao passo que os mais ricos têm uma possibilidade bem maior de ascender às ocupações mais produtivas e bem remuneradas.

Os resultados obtidos nas equações de rendimento ajustadas mostram que a influência da educação na conformação da renda não-agrícola é muito maior do que na agrícola. O motivo é que, além da taxa de retorno estimada da escolaridade ser maior entre as pessoas ocupadas em atividades industriais e de serviços, sua mão-de-obra é bem mais qualificada e mais heterogênea do que entre os ocupados no setor primário. No meio rural como um todo, enquanto quase $80 \%$ dos agricultores sequer completaram o primeiro ano do antigo ensino ginasial, nos demais setores da economia o desempenho educacional é bem melhor: mais de $55 \%$ dos trabalhadores terminaram a 5 a série, quase $40 \%$ cursaram todo o ensino fundamental e $23 \%$ concluíram o ensino médio, nível em que o efeito da educação na renda pessoal se torna bem mais elevado.

Dessa forma, embora o capital físico tenha se destacado nas estimativas como o principal determinante da desigualdade de renda agrícola no País, é a educação o fator que explica, isoladamente, a maior parcela das disparidades de rendimentos do trabalho em toda a economia rural. Mesmo nas áreas rurais oficiais, onde a participação da agricultura na renda é maior do que a dos demais setores de atividade, a contribuição marginal da escolaridade para a soma de quadrados de regressão de $14,5 \%$ é mais do que o dobro do valor da contribuição de 6,5\% da posição na ocupação, variável utilizada como proxy do capital físico. O problema é que a baixíssima escolaridade da população mais pobre influenciará para que o desenvolvimento das atividades não-agrícolas aconteça sem a redução da concentração da renda rural, atenuando seus efeitos positivos na diminuição da pobreza. 


\section{Referências Bibliográficas}

ABRAMOVAY, R. O futuro das regiões rurais. Porto Alegre, Editora da UFRGS, 2003.

BARROS, R. P., CARVALHO, M. e FRANCO, S. Pobreza rural e trabalho agrícola no Brasil ao longo da década de noventa. Mimeo, Brasília, IPEA, 2004.

BARROS, R. P., HENRIQUES, R. e MENDONÇA, R. Pelo fim das décadas perdidas: educação e desenvolvimento sustentado no Brasil. Rio de Janeiro, Ipea, 2002 (Texto para discussão no 857).

BERDEGUÉ, J. A., REARDON, T. e ESCOBAR, G. Empleo e ingreso rurales no agrícolas en América Latina y el Caribe. Documento apresentado na conferência Development of the Rural Economy and poverty Reduction in Latin America and the Caribbean. New Orleans, Louisiana, March, 2000.

CORREAA, A. J. Distribuição de renda e pobreza na agricultura brasileira. Piracicaba, Editora Unimep, 1998.

FERREIRA, F. H. G. e LANJOUW, P. Rural non-agricultural activities and poverty in the brazilian northeast. Rio de Janeiro, PUC-RJ, 2000 (Texto para Discussão, n 428 ).

FILMER, D. e PRITCHETT, L. The effect of household wealth on education attainment around the world: demographic and health survey evidence. World Bank, 1998.

FISHLOW, A. Distribuição de renda no Brasil: um novo exame. Dados. Rio de Janeiro, n.11, 1973.

GRAZIANO DA SILVA, J., MARC, J. e BIANCHINI, V. O Brasil rural precisa de uma estratégia de desenvolvimento. CNDRS, MDA e NEAD, Brasília, 2001 (Texto para discussão n 2).

HOFFMANN, R. Distribuição da renda na agricultura. In: CAMARGO, J. e GIAMBIAGI, F. (orgs.). Distribuição de renda no Brasil. Rio de janeiro, Paz e Terra, 1991.

. Distribuição da renda no Brasil: poucos com muito e muitos com pouco. In: DOWBOR, L. e KILSZTAJN, S. (Org.). Economia social no Brasil. São Paulo, SENAC, 2001. 
. Distribuição da renda no Brasil: mudanças de 2002 para 2003 e a delimitação dos relativamente ricos. Econômica, Rio de Janeiro, vol. 7, no 1, 2005.

. Distribuição de renda: medidas de desigualdade e pobreza. São Paulo, Editora da Universidade de São Paulo, 1998.

- Mensuração da desigualdade e da pobreza no Brasil. In: HENRIQUES, R. (org.). Desigualdade e pobreza no Brasil. Rio de Janeiro, Ipea, 2000.

INSTITUTO BRASILEIRO DE GEOGRAFIA E ESTATÍSTICA - IBGE. Censo Demográfico 2000: documentação dos microdados da amostra. Novembro de 2002.

LANGONI, C. G. Distribuição da Renda e Desenvolvimento Econômico do Brasil. Rio de Janeiro, Expressão e Cultura, 1973.

LANJOUW, P. The rural non-farm sector: a note on policy options. World Bank workshop on non-farm rural sector and poverty alleviation. June 1999.

MINISTÉRIO DA EDUCAÇÃO. Referências para uma política nacional de educação do campo. Brasília, 2003.

NEY, M. G. e HOFFMANN, R. Desigualdade de renda na agricultura: o efeito da posse da terra. Economia, Niterói, v. 4, n. 1, jan./jun. de 2003.

REARDON, T., CRUZ, M. E. e BERDEGUÉ, J. Los pobres en el desarrollo del empleo rural no agrícola en América Latina: paradojas y desafíos. III Simpósio Latinoamericano de Investigación y Extensión de Sistemas Agropecuários. Centro Internacional de la Papa. Lima, Peru, 1998.

REARDON, T. Rural nonfarm employment and incomes in Latin America: overview and policy implications. World Development, vol. 29, $\mathrm{n}^{\circ} 3$, março de 2001.

. Rural non-farm income in developing countries. World Bank workshop on non-farm rural sector and poverty alleviation. June, 1999.

SIMÃO, R. C. S. Distribuição de renda e pobreza no estado de Minas Gerais. Dissertação de mestrado apresentada à Escola Superior de Agricultura "Luiz Queiroz" da USP, Piracicaba, 2004.

VEIGA, J. E. Cidades imaginárias: o Brasil é menos urbano do que se calcula. Campinas, Autores Associados, 2003. 